\title{
Improving Reading Comprehension By Using Internet Of The Fourth Semester Students Of Stiba Persada Bunda
}

\author{
Gunaldi Masbiran, M.Pd. \\ STIBA Persada Bunda \\ email: gunaldim81@gmail.com
}

\begin{abstract}
The goal of this research was to get information whether the students' reading comprehension could be improved through Internet using at the Fourth Semester Students of School of Foreign Language at Persada Bunda. The cases were some students' reading comprehension still low or below standard passing of test. The research was classroom action research. The participants of this research were the Fourth Semester Students of School of Foreign Language at Persada Bunda. They are consisted of 12 students. This research was held into two cycles, each cycle consisted of three meetings. The research data were divided into two major types namely, quantitative and qualitative data. The quantitative data were taken through reading comprehension test. The qualitative data were collected through observation, and field notes. The result of the analysis showed that the students grades improved after internet using. The improvement happened on each cycle at the research. The improvement of students' reading comprehension scores were influenced by factors such as motivation, interest, and classroom atmosphere. Thus, it was concluded that internet using can improve students' reading comprehension. The internet using also increases students' speed in reading comprehension that can be used by students of School of Foreign Language at Persada Bunda. Therefore, the internet using is recommended to be used by the students and lecturer in teaching and learning reading comprehension at the School of Foreign Language of Persada Bunda.
\end{abstract}

Keywords: Reading Comprehension, Internet Using

\section{INTRODUCTION}

\section{A. Background of the Problem}

To master English we have to understand the fourth competencies in mastering language that is; Reading, Writing, Speaking and Listening. In this case reading is one of the competencies that should be understood by the students who want to learn English. From the researcher's experience and observation done to the students as the English lecturer, there were some problems which caused the students' score still low or below standard of grade ability in comprehending reading text found in teaching reading comprehension. The problem was related to students themselves. It deals with the passiveness toward reading. It could be identified their attitude from their motivation in reading. They are less of eagerness in reading English. They feel less motivation in reading subject. The next problem was students' comprehension on English reading material. This fact supported by Kustaryo (1988) states that the purpose of teaching English for students in Indonesia is to enable the students to comprehend scientific books written in English. According to Alexander (1988), there are some factors that influence the development of reading 
comprehension. These include the reading material, vocabulary, the total program of reading instruction, the learner own personality, attitude, interest, motivation and reading habit.

The last problem was related to lecturer's technique of teaching reading. The lecturer usually asked students to read, find the difficult words and answer the questions. Then, he explained the difficult word and answer the questions together. The students felt boring with the teaching technique and was not interested in them.

As a result of low reading technique and comprehension because of the problem mentioned above, students got low score in reading comprehension. In class activity, some of them did not have self confidence in reading and doing the exercises. Thus, some of them did not do the assignment well, this could be caused by lack of knowledge of reading techniques. Consequently, they often got low marks in reading subject at the end of the semester. From 12 students, only 3 students got score above 60 or $25 \%$, and 2 students got $50-60$ $17 \%$ and 7 students get score below 50 or $58 \%$. Dealing with the above problems the researcher applied a teaching strategy which might be able to enhance students' reading comprehension by internet using. Since the students of the Fourth Semester of Academy of Foreign Language at Persada Bunda, have different level of proficiency, the researcher tried to improve students' reading comprehension by internet using.

Based on the reasons above the researcher implemented a classroom action research entitle "Improving

\section{Reading Comprehension by Using Internet at the Fourth Semester Students of STIBA Persada Bunda".}

\section{B. Identification of the Problem}

Based on the background of the problem above, the researcher identified some problems:

1. The students are still less in reading comprehension of reading material.

2. The students get below standard of grade for passing score.

The fact that some of the students were still less of ability in reading, because the students themselves and some others were: less of vocabulary, reading interest, reading habit and environment.

\section{Limitation of the Problem}

There were some problems that the students faced in reading comprehension. However, in this research, the researcher limited his study and focused on the problem occurred on students at the Fourth Semester Students' of School of Foreign Languages at Persada Bunda. The problem was students less of reading comprehension. Here, the researcher used internet using in understanding reading texts.

\section{Research Questions}

The problem of this research could be formulated in the following questions:

1. To what extent can internet using improve students' reading comprehension at the Fourth Semester Students of School of Foreign Languages at Persada Bunda?.

2. What factors influence the changes of students' reading comprehension by internet using in reading text?.

\section{E. Purpose of the Research}

The purpose of this research are: 
1. To explain whether the internet using can improve students' reading comprehension at the Fourth Semester Students of School of Foreign Languages at Persada Bunda.

2. To explain the factors that improve reading comprehension of the Fourth Semester Students of School of Foreign Languages at Persada Bunda, through internet using.

\section{F. Importance of the Research}

The result of this research would be expected to give contribution both theoretical and practical values. Theoretically, this research is intended to solve the problems found during teaching and learning process in the classroom. Practically, it will be beneficial for helping students in improving and understanding their reading skill and comprehension of reading materials.

\section{G. Definition of the Key Terms}

1. Reading comprehension is an activity done by the reader to connect the ideas on the page to what they already know in order to understand and to get the idea of the text through some processes.

2. Internet is a global computer network providing a variety of information and communication facilities, consisting of interconnected networks using standardized communication protocols.

\section{REVIEW OF THE RELATED LITERATURE}

A. Review of Related Theories

1. Reading Comprehension
Reading comprehension is the process of recognition, interpretation and perception of written or printed material. It is also process of communication from the writer to the reader. It involves the recognition of the letter, words, phrases and clauses.

According to Peggy (1990), reading is the process of constructing meaning through the dynamic interaction among the reader's existing knowledge, the information suggested by the written language, and the context of reading situation.

Nation (1990) suggests that the role of reading is to develop students' language knowledge in several ways. First, reading is essentially an individual activity and therefore learners of different proficiency level could be learning at their own level without being locked into an inflexible class program. Second, it allows learners to follow their interest in choosing what to read and increase their motivation for learning. Third, it provides the opportunity for learning to occur outside the classroom. Furthermore, he adds that the role of reading is to improve students' reading fluency. Finally, it is intended to develop vocabulary.

Furthermore, Bynes (1998) adds that reading is an interactive process that goes on between the reader and the text, resulting in comprehension. The text presents letters, words, sentences, and paragraph that encode meaning. The reader uses knowledge, skills and 
strategies to determine what the meaning is.

Comprehension means readers' activity in learning to focus on important information. The comprehension check reflects the major idea of the text is in order to help the readers to focus on important information (Markstein, 1981). The theory explains that in comprehending the text, readers should reflect the major idea of the text, so that they can get important information. Comprehension is an active process and the reader must interact and be engaged with the text for it to work well (Kruider: 2002). In reading, the reader is not passive but he must relate what he knows and what he reads and he has to think to get better comprehension.

According to Adams (2000), in order to improve comprehension, the reader should establish a purpose that help them to get involved in the reading assignment such as reading for pleasure, reading for special application, reading for general idea, reading to locate specific information, reading to critically evaluate, recognizing and understanding main idea and supporting detail, understanding relationship, critical reading.

Reading comprehension is a process using synthetic and semantic information found in printed text to reconstruct in the readers mind. It is not a passive, receptive activity, but requires the reader to be active in thinking. A competence reader reconstructs a writer message. This construction of a meaning is an interactive process between the reader and the text, because the reader also makes contribution (Devine, 1986).

Moreover, Lenz (2005) says that reading comprehension is the process of constructing meaning for the text. The process of comprehending involves decoding the writer's words and then using background knowledge to construct an approximate understanding of the writer's message. Thus, the students must have some knowledge of the meaning of individual words in order to get meaning from sentences, paragraph or whole selections. When the students have lack of prior knowledge the teacher can teach vocabulary as per reading step, provide experiences by enriching the background knowledge, and introduce a conceptual framework analogous which is essential as a practical means for introducing students to unfamiliar information in the context of familiar framework (Pearson, 1984).

Furthermore, Clast (2007) states reading competencies are divided into broad categories; that are literal and critical comprehension. The literal comprehension skills are directed actual words written by the author such as selecting topic sentence of paragraph, identifying main idea of a text or passage, identifying the supporting details of text or passage, determining the meaning of words by content. 
Brown (1994:291-296)

states some strategies for reading comprehension. They are:

identify the purpose of reading, use grapheme rules and pattern to said in bottom up decoding, use efficient silent reading techniques for relatively rapid comprehension, skimming, scanning, semantic mapping, guessing, vocabulary analysis, distinguishes between literal and implied meanings and capitalize on discourse market to process meanings.

According to Muto (1998), reading can influence knowledge of lexical cohesion, he suggests to use cohesion in reading class at tertiary level and learner should initially be taught a larger productive vocabulary of at least two thousand highfrequency words. Lowfrequency words can be acquired while second language learner (L2) are exposed to reading. He also clarifies that the knowledge of discourse organizing vocabulary, especially lexical cohesion, helps students in understanding reading text.

In addition, Gates (1997)

states one suspects that cohesion is useful for coarse-grained (e.g., paragraph-sized) segmentation of topic structure, whereas coherence is more oriented towards fine-grained (clausesized) segmentation of topic structure. She also describes on text cohesion that models text in terms of relation between words or referring expressions and determine how tightly connected the text is and coherence which models text in terms of macrolevel relations between clauses or sentences to help determine the overall argumentative structure of the text.

Moreover, Mc Whorter (1986:23-24) clarifies that there are some activities for effective reading well such as: a) identifying what is important, b) determining how keys ideas that supported, c) identify the pattern of thought, d) drawing connection the ideas, e) anticipating what is come next and, f) creating the idea to what they are already known.

Based on the above discussion, it can be concluded that reading comprehension has the following indicators: topic, main idea, detail, cohesion and coherence that can be used in reading skill in order to understand reading text and applicable for reading subject, reading text book and any reading materials.

\section{Internet Using}

The iinternet is the global system of interconnected computer networks that uses the intelnet protocol suite (TCP/IP) to communicate between networks and devices. It is a network of networks that consists of private, public, academic, business, and government networks of local to global scope, linked by a broad array of electronic, wireless, and optical networking technologies. The iinternet carries a vast range of information resources and services, such as the interlinked hypertext documents and applications of the World Wide Web (WWW), electronic

mail, telephony, and file sharing. According to Cohen 1997 A Guide to Designing Interactive Teaching for the World Wide Web aids instructors in 
developing and using interactive, multimedia

educational materials on the World Wide Web. In addition Lewin (2001) stated that internet can strengthen curriculum. It also helps instructors organize and control these resources for their students' use. Not only do instructors learn how to improve their own materials and delivery, but they can access and make available Webbased information in a way their students can comprehend and understand the material

\section{What is the Internet?}

The internet is made up of millions of computers linked together around the world in such a way that information can be sent from any computer to any other 24 hours a day. These computers can be in homes, schools, universities, government departments, or businesses small and large. They can be any type of computer and be single personal computers or workstations on a school or a company network. The internet is often described as 'a network of networks' because all the smaller networks of organizations are linked together into the one giant network called the internet. All computers are pretty much equal once connected to the internet; the only difference will be the speed of the connection which is dependent on your Internet Service Provider and your own modem.

2. What do you use iinternet for? There are so many things you can do and participate in once connected to the internet. They include using a range of services to communicate and share information and things quickly and inexpensively with tens of millions of people, both young and old and from diverse cultures around the world. For example:

a. You'll be able to keep in touch and send things to colleagues and friends using electronic mail, internet telephone, keyboard chat and video conferencing.

b. You can also tap into thousands

of databases, libraries and ne wsgroups around the world to gather information on any topics of interest for work or recreation. The information can be in the form of text, pictures or even video material.

c. This means you can stay up to date with news, sports, weather and any current affairs around the world with information updated daily, hourly or instantly.

d. You can also locate and download computer software and other products that are available in cyberspace

e. You can listen to sounds and music, and watch digital movies

f. There are also a growing number of interactive multimedia

games and educational tools. And as well as using the internet for receiving things you will be able to publish information about your development work experiences, community, school, hobbies or i nterests. 


\section{How to do a search?}

Finding resources on the iinternet can be like looking for a needle in a haystack. There are millions of documents on the iinternet, published by specialists, scientists, teachers and students. Some of them will be useful for your research project; the trick is in finding them!

One of the easiest and safest methods of researching for relevant resources is by using ddirectories that have already been evaluated by other organisations. Directories are collections of resources organized into categories. Sometimes the directory will focus on one subject area, others may collect and organize resources in a number of areas. Internet is not like your school library, with its shelves of well organized books. Simply browsing the internet is unlikely to find you the information you need, so in order to find the resources you want for your research project, you will need, at some point, to use a search engine - a tool used to search for information on the internet.

Search engines compile databases of web pages which allow users to search the internet for specific resources, by doing what is termed a keyword search. When a user types in a search request such as "Egypt", the search engine already knows where all the pages that include the word "Egypt" are located. When you are using a search engine it's important to clearly define your keywords. You need to be specific rather than general, because there is so much information out there; a general search may return you hundreds of thousands of hits. In order to avoid being overloaded with information, think carefully about what you are searching for. For example, a search for the word "cat" returned 500,000 hits! But a search for "cat health" returned only 200 hits, still a large number, but much more useful.

Before you start your search think about what you are looking for and do some groundwork with a pen and paper. Think of all the possible terms you might use for your subject. Think of any differences there may be in terminology from country to country. For example, in South Africa we talk about primary schools, in the US the term is elementary school. So a search for "primary school" might not find you information about American schools. Of course this might be an advantage if you were only looking for information about South Africa.

\section{How to treat information and} sources

Finding the information you want on the iinternet is only the first step. There is a lot of material available, but not all of it is equally reliable and useful. If you are doing research, a large part of your job is not simply to find information, but to make judgments about its merit. Before you use any material you have found, you need to spend some time evaluating it for accuracy and importance. Use the following questions as a 
guide, but also use your own experience and skills to make a decision. The source of the material might give you a clue to its reliability. A site maintained by a university or government organization might be more reliable than one maintained by a private citizen.

Sometimes the age of information matters. If you need current statistics then check the age of the material you have found. As a rule, in most fields anything more than five years old is probably out-dated. But a site which deals with historical information may not need updating as frequently as one which is all about the latest political events. Just because information isn't regularly changed doesn't mean you shouldn't use it, but you need to be aware that your information is not necessarily the most recent.

The status of the writer is often of considerable importance in deciding the reliability of information. You can probably assume that material written or otherwise provided by a known expert in the field is likely to be reliable. Resources provided under the auspices of a recognized institution might be considered reliable as well. But what about student pages on a university server? Just because you have never heard of the author of the page doesn't mean that the information is inaccurate or unreliable, but it does mean that you can't take it at face value. You might have to do some cross-checking, either elsewhere on the net, or with books or articles.

Who put the material on the Internet and why? Think about whether they might have some reason other than pure helpfulness for posting information. Many special interest groups have web pages, and while this doesn't necessarily mean the material is biased it is something you need to think about. All sorts of groups now have web pages on the Internet, and obviously all of them have a message they are trying to get across. Think about what is being said, and why the material is there.

Think about ways you might cross check the information you have found. You might have a look at another site with similar material, ask somebody who knows something about the topic, and have a look at book on the subject. Use your own experience as well. If you have already done some research in the area you will already have some knowledge of the subject. How does this material fit in with what you already know?

Referencing (also called citing) simply means that you indicate which material is not your own and show where you got it from. Even if you have not used someone's exact words, but have rephrased their ideas you need to give your sources. The idea is that someone else reading your work should be able to recognize the difference between your work and someone else's. You need to provide them with enough information about your sources 
that they could find the source for themselves.

There are several different referencing systems, each subject area tends to use it's own system of citations, but whatever style you choose it is important to be consistent, complete and accurate. This is matters not only for books and articles, but electronic sources as well.

Plagiarism is theft. If someone broke into your house and stole your television you would be understandably upset. That was your television and now you can't watch In exactly the same way, using someone else's ideas without acknowledging where they came from is stealing.

That is what referencing is all about, making sure that you if you use someone else's words or ideas, you let your readers know where the information came from. It is okay to quote from a book, or use the ideas from someone's work in your own work, but it does mean that you need to be careful to make sure that you acknowledge where the information came from, and make it quite clear that it is not your own original ideas. The way you do that is to make sure you reference any material you use which is not your own. Referencing resources from the Internet

You need to include:

1. The author's name (if known);

2. the full title of the work;

3. the title of the complete work if applicable;

4. the document date if known;

5. the full URL

6. the date of visit.
For students wishing to improve their reading skills these days, there is nothing better than the Internet to provide a wide range of opportunities, resources, and links to find anything from beginning readers to literature passages that test and challenge reading skills. Studies have shown that using the Internet to improve reading and English writing skills provides students with a wide range of selections that prevent boredom and provide entertainment.

Students who learn and improve their English reading skills through various computer software programs or Internet resources find that global interactions via forum boards and blogging helps them to make personal connections with others learning at their speed, and also provides them with help and guidance along the way. This article will illustrate some of the many ways students may improve their English reading and writing comprehension through the use of the World Wide Web.

\section{METHOD OF RESEARCH}

\section{A. Type of the Research}

The researcher used classroom action research in which the researcher used cycles. According to Mettetal (2001:1) states that classroom action research was a systematic enquiry with the goal informing practice in a particular situation. To support this idea, Burns (1995:93) clarifies that the application of facts findings in the classroom action research is the practical problem solving in social situation with a view to improve the quality of action that involves and cooperation of researcher, practitioner and others.

Gay and Airasion (2000) note some purpose of action research: 1) To find the problem and to find the 
solution, 2) The researcher should change a situation so that it is the same to her or his preference. 3) To effect teacher action, belief and activities. 4) To study and to increase their own teaching activities.

Based on the explanation above it can be concluded that classroom action research is a kind of research that is done by the lecturer to solve the problems found in the classroom. The purpose of the research is to improve the quality of the lecturer and the students' mastery in material to be taught by lecturer in teaching and learning process. Lecturer finds out a solution on how to overcome the problems.

In this research, internet using research was used. In this case, the researcher and an English lecturer becomes a team who work together to overcome the problem faced in teaching reading.

\section{B. Location and Participant}

The location was at School of Foreign Languages of STIBA Persada Bunda Foundation at Jl. Diponegoro No. 43, Pekanbaru, Riau Province. The participants of this research were the Fourth Semester Students of School of Foreign Languages of STIBAPersada Bunda. It was done at the fourth semester students that consists of 12 students. The researcher chosen the fourth semester students was based on the observation on daily teaching activity. The students had lack reading comprehension and achievement in reading comprehension.

\section{Instrumentations}

Instruments were used in this research, as the followings:

1. Test

The test was one of the important instruments in this research in order to know the problem and solve the problem of reading by internet using. The tests were given in this case was pre-test and post-test. The aim of this tests were to know students ability about reading material. The second were post-test to measure how far the students could improve their reading ability in reading and understanding paragraph through internet using. The tests were written test. In this case the students were expected to understand reading text by reading title and introduction, first sentence in each paragraph, coherence, cohesion, italic and boldface word, and the last summary or conclusion. The tests were made by the researcher.

\section{Interview}

The interview was an instrument which consist of some questions that the students should answer which related to the indicator described in the review of related literature. The indicator consist of title/introduction, the first sentence and last of each 
paragraph, details and summary or conclusion. Thus, the students were hoped to answer the questions well that was given in English.

D. Techniques of Collecting the Data

The data were collected by doing 1). test, 2). and interview. The observation were conducted by the lecturer as the researcher and it was done during teaching and learning process at every meeting. The observation was prominently focused on the developments of students' reading comprehension and factors that influenced reading achievement. Meanwhile, the data from interview were collected after teaching and learning process of every meeting. The interviews were be done by the lecturer as researcher. The students were interviewed to find out whether internet using can improve reading comprehension and what factor influence the improvements.

E. Techniques of Analyzing the Data

Since there were two kinds of data, qualitative and quantitative data, thus the analysis of the data covered in to:

\section{Quantitative Data}

Quantitative data which were presented in the average score were analyzed and interpreted by comparing the data from one meeting to the next meeting and from one cycle to the next cycle. Then the result of the comparison was shown in average and the form of graphs. To find out the average of improved students reading comprehension, the researcher used the formula as the followings:

Mean:

$\bar{X}=\frac{\sum X}{\sum N}$

$\bar{X}=$ Average score

$\sum X=$ Total amount of score

$\sum N=$ Total amount of participants (respondent)

$\mathrm{X}$ (the sum of students done)

Percentage (P)

$\overline{100 \%}$

students)

$\mathrm{N}$ (the number of the

(Arikunto: 2007)

\section{Qualitative Data}

Furthermore, qualitative data were analyzed and interpreted verbally. The researcher explained the changes or developments made by students dealing with their learning reading comprehension and explain the factors that cause the changes or the developments. The explanation was made based on the graphs from qualitative data. By analyzing the data qualitatively, it was shown what factors make students' reading comprehension increase or decrease which was shown by the graphs. Gay and Airasian (2000:239-241) stated some steps in analyzing qualitative data as the following:

1. Data managing and memorizing

The data was ordered to be studied. This managing data involved creating and organizing the data and checked for completeness and to start the researcher on the process of analyzing and interpreting the data. 
2. Reading and memoing

The researcher read the data that had been collected to get sense of data. It is important to write note or underline that seem important for researcher so the researcher would have recorded of his initial thought and sense of data.

3. Describing

The data gotten during the research were described in order to provide detail information about setting, participants, and activities. The aim of this step was to provide a true picture of setting and events that take place of this research

4. Classifying

It means that a process of breaking down the data into smaller unit, determining the import of this unit, and putting the units together again in an interpreted form. The researcher would order the data collected into categories that represent the different aspect of data. Breaking down the data into categories in different aspect is very important to give interpretation to the data later on.

5. Interpreting

The researcher determined how the result of the student's ability in comprehending the reading is, what aspect make them are able to achieve the abilities, and how the teaching and learning process were during the application of the strategy.

\section{FINDINGS AND DISCUSSION}

This chapter discusses about the result of the research from planning, action, observation, and reflection. This research was done in two cycles. There were three meetings in every cycle. Each cycles consisted of four phases. They were planning, action and observation, evaluation or reflection. As explanation in the previous chapter, from the researcher's observation and experience in teaching reading comprehension in the classroom, he found that most of the students were less of comprehension when they were asked to read especially to read English reading text or reading subject in the classroom.

Based on the problem, the researcher interviewed and asked some questions to the students why they had difficulties in comprehending reading text. There were some answers of the students that made them in that condition. They were lack of comprehension because they did not know how to read English texts and the technique used to comprehend the English text. In other word their condition was as the effect of reading technique.

\section{Cycle 1}

\section{Plan}

I decided the time schedule of the research. It was planned that each cycle consisted of three meetings. The first cycle started on 15 February up to 15 March 2020. The researcher prepared some forms of observation checklist to record the student's activities during the process of teaching and learning. The implementation of internet using in the first cycle was done by applying the lesson plan and reading text that had been prepared at the planning. 


\section{Action}

The implementation of the action research in the first cycle was done in three meetings, there was meeting a week. In the classroom activity, the researcher as lecturer began the class by greeting the students and took attendance. The lecturer informed the students that he was going to do research and gave pre-test for the students in order to know the students' background about the reading. Then, the lecturer explained about how to understand the reading text by giving examples and exercises by using reading text.

After explaining about paragraph, the students were asked to do the exercises to about reading and use internet as media for helping them in doing the exercises for example to main main idea, detail, and to find difficult word, etc. While the students were doing the exercises, lecturer monitored the activities that were done by students by using observation sheets.

For the second meeting, lecturer came to the class and check the students' attendance. Then the lecturer lead the students' to check students' works and asked them to conclude the understanding of paragraph in learning process by using observation sheet.

For the last meeting of cycle 1, lecturer gave more explanation how to find main idea, detail, and difficult words in a reading text by using more example of paragraph. To make students more understand the way how to find main idea, detail, and difficult words in a paragraph as exercises as homework.

Finally, the lecturer gave post test to the students to see how well they could understand paragraph especially in finding main idea, detail, and difficult words. The students regarded success in comprehending paragraph if they got score above 65 . The test that was given in post-test was the same with the test in pre-test, in order to compare students' competency before and after teaching and learning process. This was also to see how far learning could increase students' ability in understanding paragraph as the purpose of this research. Students' mark in pretest and post-test in cycle 1, can be seen in table 1

\begin{tabular}{|c|c|c|c|}
\hline \multicolumn{4}{|c|}{$\begin{array}{l}\text { The First Circle of Research Reading Comprehension Score of Semester } 4 \\
\text { Students }\end{array}$} \\
\hline No. & Students & Pre-test & Post-test \\
\hline 1 & Students A & 55 & 65 \\
\hline 2 & Students B & 60 & 70 \\
\hline 3 & Students C & 50 & 60 \\
\hline 4 & Students D & 45 & 65 \\
\hline 5 & Students E & 65 & 75 \\
\hline 6 & Students F & 50 & 60 \\
\hline 7 & Students G & 50 & 65 \\
\hline 8 & Students H & 55 & 65 \\
\hline 9 & Students I & 60 & 70 \\
\hline 10 & Students J & 40 & 50 \\
\hline
\end{tabular}




\begin{tabular}{|l|l|l|l|}
11 & Students K & 60 & 75 \\
\hline 12 & Students L & 70 & 80 \\
\hline Average Score & & 55 & 67 \\
\hline High Score & 70 & 80 \\
\hline Lowest Score & 40 & 50 \\
\hline
\end{tabular}

From table 1 it could be seen that the students who got passing grade score in at pre-test were 5 students $(42 \%)$ and after conducting reading by using internet where they could search many reading material and any journal publication they can increase their score become $92 \%$ of students fulfill passing score that is above 60 score.

\section{Reflection}

Based on the result of observation students activities in learning process and result of post test cycle I, it could be concluded that internet using was able to increase students 'comprehension in reading text.

However, the increasing was not satisfied yet. After the researcher analyzed and make giving more focus on exercise especially internet of reading material searching so the research would be continued to cycle 2 by improving technique and strategy in teaching and learning trough internet. In this case the researcher would focus on the problem of the way how to do activities in strategy to find reading material by internet.

From the analysis of observation of students' activities, there are some problems existed still exist. They were:

1. Students were not actively involved asking question and discussion

2. Students were not brave enough to give comment

3. Lack of students were creativity in learning
4. Students were hard to make conclusion

In conclusion, it could be concluded that some problems could not solved yet. The students were not actively participated yet because they did not understand the way what to do in internet using. The students also could not interact among their group member so that they did not get what they hope from learning process. For the next cycle the researcher would focused on the material to chosen for example research material, or international journal.

\section{Cycle 2}

It was done for three meetings. The researcher also prepared the materials and lesson plan. The material are reading texts.

\section{Plan}

The action plan for this cycle were based on the problems that were found in cycle 1 . The plans were set up such the following:

1. Redesigning the activities in the class with more focused on the appropriate technique in doing learning activity.

2. Prepare reading text that are going to be discussed together in group

3. The teacher gave more explanation about understanding reading or paragraph

\section{Action}

For the first meeting the researcher came to the classroom 
chosen based on the schedule and did the teaching procedure that has been stated in the lesson plan. The implementation of the action research in the second cycle was done in three meetings, there was a meeting week which were held on every Monday in the evening.

In the classroom activities the teacher started the lesson by saying good evening to the students, and the teacher check students attendance. Then researcher inform the strategy in finding qualified reading text and the target that is going to be reached as long as teaching and learning process by giving information about the result of pre-test and post test in cycle 1 and some weaknesses that was found by lecturer.

After the teacher explained about some strategies, the students were asked to discuss in group and researcher distributed the worksheet to each group. Each member of the group has responsibility with their task. While the students were working in the group, researcher monitored the activities that were done by students by using observation sheets. The researcher inform to the students that the activities would be continued at the second meeting by presenting the result of their discussion.

For the second meeting, the lecturer came to the class and check the students' attendance. The teacher explained the way how to report the result of internet using technique. Lecturer monitored the students presentation in reporting their task by using observation sheet. The next activity, the lecturer and students made conclusion about how to understand reading passage in case by searching reading material in internet.

The third meeting, the lecturer came to the class and checked students' attendance. Then the teacher gave more understand the way how to find topic, main idea, detail, cohesion and coherence in paragraph by using some more example of paragraph. To make students more understand the way how to find topic, main idea, detail, cohesion and coherence, the teacher gave students some paragraph as exercises. Students did the task individually, the result of exercise are discussed together.

Finally, the lecturer gave posttest to the students to see how well they could understand paragraph especially in finding topic, main idea, detail, cohesion and coherence. The result of the test was corrected by the collaborator in order to make them objective, and the students' mark in pretest and post-test in cycle 2 can be seen in table 2 .

\section{First \& Second Circle of Research Reading Comprehension Score of Semester 4 Students}

\begin{tabular}{|l|l|l|l|l|}
\hline & & & & \\
\hline 1 & Student A & 65 & 75 & 70 \\
\hline 2 & Student B & 70 & 80 & 75 \\
\hline 3 & Student C & 60 & 70 & 65 \\
\hline 4 & Student D & 55 & 65 & 60 \\
\hline 5 & Student E & 75 & 85 & 80 \\
\hline
\end{tabular}




\begin{tabular}{|c|c|c|c|c|}
\hline 6 & Student $\mathrm{F}$ & 60 & 70 & 65 \\
\hline 7 & Student G & 60 & 70 & 65 \\
\hline 8 & Student H & 65 & 75 & 70 \\
\hline 9 & Student I & 70 & 80 & 75 \\
\hline 10 & Student J & 50 & 60 & 55 \\
\hline 11 & Student K & 70 & 80 & 75 \\
\hline 12 & Student L & 80 & 90 & 85 \\
\hline \multicolumn{2}{|l|}{ Average Score } & 65 & 75 & \\
\hline \multicolumn{2}{|l|}{ High Score } & 80 & 90 & 70 \\
\hline \multicolumn{2}{|l|}{ Lowest Score } & 50 & 65 & \\
\hline
\end{tabular}

Based on the reflection, the researcher and collaborator agreed that the action research in applying internet using for students at School of Foreign Languages of the fourth semester students was successful enough.

At the end of this cycle the researcher gave questionnaire to the students about the process of the improvement through internet using.

\section{CONCLUSIONS}

AND

\section{SUGGESTIONS}

\section{A. Conclusions}

From the result of this research that was conducted in two cycles, it can be concluded that:

1. Internet using in reading also increase students' reading comprehension. It can be seen from the result of their test for every cycle. Their mark is better than before applying internet using. Internet using improved teaching and learning process at the Fourth Semester Students' of School of Foreign Languages. They are brave enough to ask question, give comment, got the conclusion about the task given by themselves, and share idea among their friend.

\section{Table 2}

2. The factors the that influence the changes reading comprehension by using internet:

a. The students knew about topic, main idea, detail which found in the reading text.

b. The students could know and find about cohesion and coherence in reading text well.

c. Classroom atmosphere made them interest in study and read English reading text.

d. The reading texts given to them were familiar to them to understand.

\section{B. Implication}

Based on the conclusion above, there are two kinds of implication of this research. They are: The use of internet is one of the alternative, that can be applied in teaching to improve students' learning process, students' achievement, and students' comprehension. The lecturer needs more knowledge to handle classroom in teaching and learning process especially by using internet in order to make the process of learning and teaching enjoyable. 


\section{Suggestions}

Based on the findings and discussion above, the researcher suggested:

1. English lecturer can use internet to make reading comprehension easier for students.

2. English lecturer should provide strategy for teaching by internet using and provide students with valuable exercise and reading material.

3. In applying internet using, it is suggested that the English lecturer pay more attention to students activities in group discussion.

4. The lecturer should provide the students with reading texts that are relevant to their education, experience and knowledge.

\section{References}

Adams, W. Royce. 2000. A Guide for better Reading and Self Teaching Guide. New York: Mc.

Graw Hill Coy.

Alexander, J Estill, (Ed). 1988

Teaching Reading (3rd ed)

London: Scot Foresman and Comp.

Arikunto, Suharsimi. 2008. Metodologi

Penelitian. Edisi Revisi VI. Rineka Cipta: Jakarta

Brown, H Douglas. 1994. Teaching by

Principle. An Interactive Approach to Language Pedagogy. New

Jersey: Prantice. Hall Regents.

Burns. Robert. B. 1995. Introduction to Research Methods. Sydney: Longman Australia Pty. Ltd.
Clast. 2007. Reading Comptencies Tested on Standardized Exams. http://www.lit.msu.edu./vpllnuml/c hun-plass. Retrieved on 20 August 2009

Cohen C. Karen. 1997. Internet Links for Science Education.Plenum Press. New York and London

Devine, Thomas G. 1986. Teaching Reading Comprehension from Theory \& Practice. Boston: Allyn and Bacon

Gay, R.L. and Airasian. 2000. Educational Research. New Jersey: Prentice Hall

Gates, Barbara. 1997. Using Cohesion and Coherence Models for Text Summarization. Reston: The Mitre Corporation.

Kustaryo, Sukirah. (1988). Reading Techniques for College Students. Jakarta: Departemen Pendidikan dan Kebudayann Direktorat Jendral Pendidikan Tinggi.

Lenz, Kedith. 2005. an Introduction to Reading Comprension. Retrieved on November. 23rd, 2007 at egiwrap/speeconn/main php.

Markstein, Linda. And Louise Hirasawa. 1981. Developing Reading

Skills.Messachusetts:Newburry House Publisher.

Mettetal, Gwynn. 2002. Improving Teaching Through Classroom Action Research. South Bend: University of Ilinois.

Mc Whorter, Kathleen. T. 1986. Guide to College Reading: Boston: Little Brown and Company. 